\author{
Eka LeKashVILI* \\ Ivane Javakhishvili Tbilisi State University \\ Veko DodashVILI** \\ Ivane Javakhishvili Tbilisi State University
}

\title{
LEGAL REGULATION OF TOURISM BUSINESS IN GEORGIA
}

Keywords: Georgia Economy, legal regulation, tourism business.

J E L Classification: A1, K2, L51.

Abstract: Research objective: Georgia, as a country favorable for tourism, can offer the various types of tourism products and therefore, is presented as an attractive country for travelers. The research aims: to analyze tourism business legal framework in Georgia, the basic laws and regulations, evaluate the tourism industry in the context of current legal environment and offer the recommendations for stimulating and supporting legal reforms.

The theoretical and methodological basis of the study: We will discuss tourism business in Georgia in the regulatory legislative framework, including the Law of Georgia "Tourism Law" (1997), the Law of Georgia "On Resorts and Resort Sanitary Protection Zones" (1998), the Civil Code of Georgia (tourist services: Articles 657-667), The Tax Code (regulates the activities of the tourism industry), The Law of the Free Tourist Zone Development and several other government orders and the commands of the Ministry of Economy and Sustainable Development.

The research results will summarize Georgia's tourism industry regulatory legal framework for its positive and negative sides, the issues, which remain beyond the legal regulation and offer various recommendations, which, with its practical meaning,

Date of submission: February 27, 2017; date of acceptance: May 29, 2017.

* Contact information: eka.lekashvili@tsu.ge, 14, Ave. Vaja Pshavela, Tbilisi, Georgia, phone: +995 599899809 .

** Contact information: veko.dodashvili@gmail.com, 14, Ave. Vaja Pshavela, Tbilisi, Georgia, phone: +995 577751751 . 
will be essential for tourism policy makers, local and international tourism agents. In addition, it is important to analyze the national legislation and to fill the EU-Georgia Association Agreement within the framework of the harmonization of the laws effective.

\section{IIIITRODUCTION}

Tourism is one of the major and fastest-growing fields of modern global economy. It is a leading and profitable service sector. In terms of economic development and revenue mobilization, development of the tourism industry is immensely important for Georgia as a country with diverse tourism resources. Georgia, as a country beneficial for tourism development, can offer a big variety of products to consumers, which makes it attractive to tourists. It is noteworthy that since 2013 tourism has been pronounced a priority field of the economy of Georgia.

Between 2009 and 2013, the growth rate of tourism in Georgia was one of the highest worldwide: The gross number of international travelers increased by $300 \%$ - from 1.5 million to almost 5.4 million (The Tourism Development Strategy for Georgia 2015/2025, 2015, p. 8) According to the aggregate data obtained in the first three quarters of 2015, the value created in the tourism industry increased from 1.39 billion GEL to 1,508 billion GEL. Its share in GDP increased up to 7.1\%. Most of the international arrivals - $87.8 \%$ (5 176 887) were from neighboring countries. Only $12.2 \%$ of arrivals were from other countries. In terms of the growth of international arrivals, Israel $(+40.3 \%)$, Kazakhstan (29.5\%) and Russia (14.0\%) rank highest. Supposedly, activation of these countries affects the growth of their expenditures in Georgia (National Statistics Office of Georgia, 2016). Data of the National Tourism Administration shows the dynamic growth of the country's international tourism receipts, which has been recently reflected on the growth of GDP in tourism industry shares (see figure 1). If the Tourism Value Added (thousands of GEL) in 2006 was 872274 GEL, in 2016 the same indicator grew to $2059781 \mathrm{GEL}$. At the same time, the indicator of Foreign Card Operations and International Travelers in 2010 was 376788 GEL while in 2016 it was increased by 5 times to $624808 \mathrm{GEL}^{1}$. These positive tendencies underline the growing influence of the tourism sector for the country with poor financial revenues.

1 http://gnta.ge/statistics/ (accessed: 04.05.2017). 
Figure 1. International Tourism Receipts (Thousands of USD)

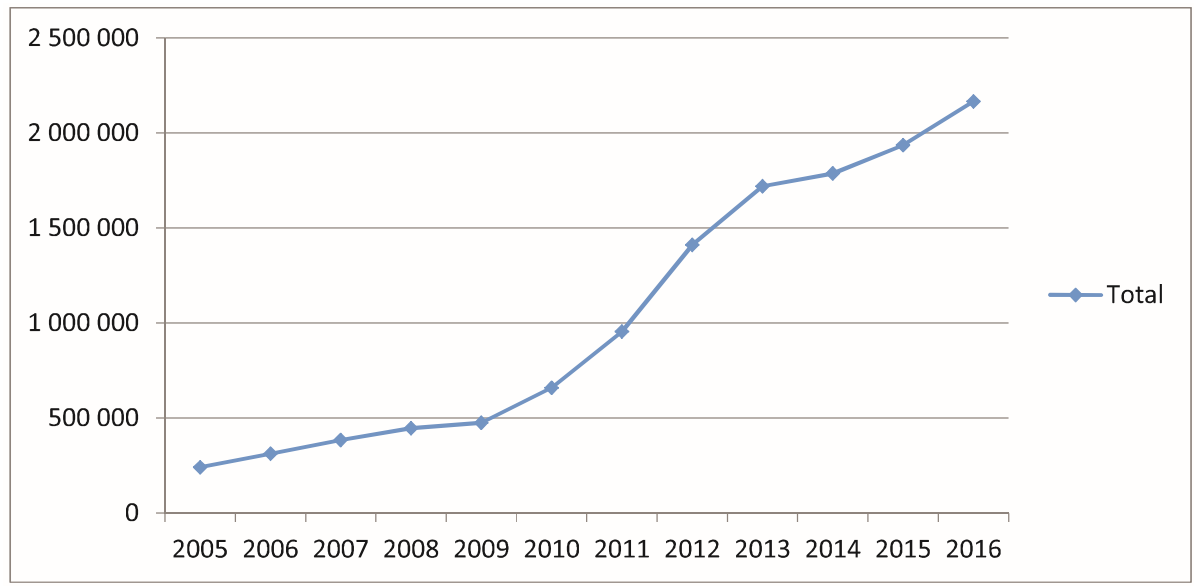

S o u r c e : own study based on: http://gnta.ge/statistics/.

Tourism is one of the fastest-growing industries in Georgia, the local development of which has largely been supported by the government of Georgia for the last few decades. This is manifested through the improvement of the business environment as well as through the increased number of visits, establishment of a favorable environment for foreign and domestic investments and various other indicators; however, there is still a lot to do to eradicate flaws in this area. We deem challenges concerning problems related to infrastructure are due to the imperfect legal regulation. Although the Parliament of Georgia has adopted a few laws in the last few years and the government issued various orders, several issues in the tourism business require a more concrete legal regulation.

The study aims to analyze and systematize the legal framework of Georgia, major laws and normative documents in order to regulate the tourism business, to assess the legal environment for the development of the tourism industry and to detect problems that hinder the formation of a stimulating, favorable legal environment for the development of this field. 


\section{RESEARCH METHODOLOGY AND THE COURSE OF THE RESEARCH PROCESS}

The theoretical and methodological basis of studying the problem includes the legal framework regulating the tourism business in Georgia including the Law of Georgia on Tourism and Resorts (1997); the Law of Georgia on Sanitary Protection Zones of Resorts and Resort Places (1998); the Law of Georgia Civil Code of Georgia (June 26, 1997. Tourist services: Articles 657-667); The Law of Georgia Tax Code of Georgia (September 17, 2010. Regulating the activity of a tourism enterprise); The Law of Georgia on Supporting the Development of Free Tourism Zones (October 26, 2010) and a few resolutions of the government and orders of the Minister of Economy and Sustainable Development of Georgia. It is noteworthy that as Georgia has been a member of the World Tourism Organization since 1993; in 1994, the Parliament acknowledged the Tourism Bill of Rights and Tourist Code ${ }^{2}$ by which the country, as a member state, took on responsibilities to fulfill it.

Apart from engagement with multilateral organizations specializing in tourism, bilateral international governmental and nongovernmental agreements, that help promote stronger cooperation in the field of tourism, are also noteworthy. By now, Georgia has signed bilateral agreements on cooperation in tourism with 18 countries. Moreover, it has been a member of the United Nations World Tourism Organization since 1993.

Tourism Policy Framework plays a decisive role in ensuring tourism development stimulating policy, which is defined as a legal document and regulates economic activities in this field. Creating the perfect legal environment is the main condition for developing not only the local sector but for foreign business industries and investors. Therefore, the issue of this article is relevant not only in scientific but for practical terms. The goal of the research was to systemize the legal regulation of Georgian tourism industry, which will give a hand to researchers and practitioners to understand the framework of tourism policy in Georgia. At the same time, particular aspects of legal regulation of Georgian tourism industry were the topics of only by economics (Metreveli, 2004; Mikeladze, 2016; Abuladze, 2008; Korghanashvili, 2012). However, the researches done by above mentioned economists are done with respect to various tourist's products and its separate aspects of legal restrictive barriers. The systemati-

\footnotetext{
${ }^{2}$ See: http://www.aitr.org/wp-content/uploads/2014/04/omt_sofia1985.pdf (accessed: 21.06.2016).
} 
zation of tourism legal regulation provides us with the ability to understand the legal environment, to identify the shortcomings and the possibility of its perfection.

\section{THE OUTCOMES OF THE RESEARCH}

Under the Law of Georgia on Tourism and Resorts, the term "tourism" is defined as "free, voluntary, temporary movement of people from their place of residence for leisure, recovery, visiting historical and cultural monuments and/or for other purposes"; as for tourism activity, in Paragraph 11 of Article 2 of the same law, it is defined as "services rendered by an entity engaged in tourism activity including accommodations, catering, tour operations, transportation, excursions, recovery, rehabilitation, advertising, informational, cultural, sports, domestic, entertainment, etc. services for satisfying tourist requirements".

As for the characteristics of the regulation of tourism activity, it is, above all, important to consider the aspects of tourist services determined under the Civil Code of Georgia. In particular, the relationship between a tourist service provider and consumer is regulated under a document ("Tourism Contract") signed by and between a traveler (tourist) and a travel organizer (travel agency).

Importantly, a tourism service package consisting of not less than two components of tourism service (food, overnight accommodation, transport services, etc.) shall not include false, inadequate and misleading information. In addition, prior to signing an agreement related to this package, the tourist shall, in a written form or in a form acceptable to him, be provided with detailed information about the package price, payment methods and schedule; destination and goals, available means of transportation and their description; type, location and category of accommodation, quality and classification and other basic characteristics of service; food; passport and visa; Issues related to excursions. It is important that a tourist service provider is obliged to provide this information.

Apart from these issues, Chapter Eleven of the Civil Code of Georgia, determines the rules for changing and calculating the initial price as well as the obligations of a travel agency. For instance, within twenty days prior to the departure, the package price shall not be subject to increase; however, if a travel agency, due to reasons beyond its control, has to make significant changes to the basic terms of the agreement before the departure, it shall immediately notify the tourist of this so that the tourist can make a decision whether to terminate the contract or to accept it with changed terms. Under the same chap- 
ter, prior to the beginning of the travel, the tourist may demand substitution of a third person to travel in his place. The travel agency may refuse to substitute the third person if the latter does not qualify for the travel, taking into account the necessary conditions thereof. This chapter also includes the right of a tourist to demand compensation of necessary expenses occurred due to the shortcomings of the travel or to demand reduction of the price or termination of the contract, if the travel agency fails to eliminate the shortcomings within a reasonable period of time fixed by the tourist.

The limitation period for claims by the tourist is six months. This period begins to run from the date at which the travel should have ended under the contract.

As for repudiation of the contract before the beginning of the travel, if the tourist makes such a decision, the travel agency shall be deprived of its right to receive the agreed compensation.

Another important issue in the tourism business is related to the regulation of the economic activity of a tourism enterprise regulated by the Law of Georgia Tax Code of Georgia. Under Article 26 of the Law of Georgia Tax Code of Georgia, a tourism enterprise is a legal entity that builds a hotel, supplies hotel assets/part of the assets to another person (with or without the right to buy back the assets), and on the basis of a commutative contract (including on the basis of a lease, right of use, trusteeship, intermediary and/or other contract terms) concluded with the buyer of this property ensures that the hotel assets/ part of the assets are used as hotel rooms/apartments. The status of a Tourist Enterprise shall be assigned to a person by the Revenue Service. The procedure for according the status of a Tourist Enterprise to a person as well as the procedure for its operation and cancellation shall be determined under the resolution of the government of Georgia ${ }^{3}$.

If an enterprise specializes in tourism and operates in Georgia, it pays the profit tax; the enterprise shall incur an obligation of a tax agent towards employees and shall withhold paid salaries at source and pay the income tax to the budget; bringing of tourists to tourist sites in the territory of Georgia in an organised manner and delivery of tourist service packages to them in the territory of Georgia by tour operators shall be exempt from VAT with the right of deduction (Subparagraph (p) of the fourth part of Article 168 of the Tax Code

3 Resolution N279 issued by the government of Georgia on June 23, 2015, Tbilisi. 
of Georgia); the company shall pay the property tax (local tax) if it has fixed assets. Also, if the company owns a parcel of land, it shall pay the tax on the use of resorts and the resort tax, but it is exempt from the hotel tax. It is also important that a company does not need to get a license to provide tourist service.

The issue of tax privileges, which concerns not only tour operators but also tourist agencies and high-mountain areas, is also important. Regarding the latter, legislative changes came into force on January 1, 2016.

Under Subparagraph (y) of the first part of Article 99 of the Tax Code of Georgia, profits earned by a tourist enterprise from a gratuitous supply of goods and/or services by the state shall be exempt from the profit tax.

Under the first and second parts of Article $133^{2}$ of the Tax Code of Georgia, remuneration paid by a tourist enterprise to a natural person under a relevant contract shall be taxed at the rate of $5 \%$ of the amount taxed at source. In this case, the income received by a natural person, which is taxed at source, shall not be included in the gross income of the receiving person and shall not be subject to subsequent taxation.

Investors, investing money in the tourism business, enjoy significant benefits. Accessibility of private property through privatization, purchase of privatized property through direct buying, significant discounts on privatized property and favorable conditions for privatization in Tbilisi and regional centers - these are the privileges that an investor is granted provided that he invests in a hotel.

Apart from this, free tourist zones have been created in Kobuleti, Anaklia and Ganmukhuri in order to encourage the hotel business. The Law of Georgia on Supporting the Development of Free Tourism Zones, the purpose of which is to develop tourism and promote entrepreneurship in Georgia by determining the conditions, as well as tax and other privileges, for the construction and operation of hotels in free tourism zones, should also be noted. This law defines the rights and obligations and preferential treatment of investors, activities to be implemented by the state as well as the procedure and responsibilities for transferring parcels of land into the ownership of investors.

Moreover, investors that invest over 1 million Gel in building a hotel, will enjoy the following privileges: Free parcel of land for the nominal price of GEL 1; Free hotel design; Free casino license for the construction of a hotel with over 100 rooms; Exemption from profit and property tax for 15 years; Exemption from the construction permit fee; Provision of the territory with engineer utility networks and proper external infrastructure; and Awarding the status of 
a facility of particular importance provided by the legislation of Georgia to the hotel and getting a construction permit under a simplified procedure.

The issues of standardization, certification and licensing of service in the field of tourism are interesting. Regarding this issue, under Article 8 of the Law of Georgia on Tourism and Resorts, in order to register a licensed entity specializing in tourism and resorts, state registry exercised by the local management body of the field was introduced. This is where one of the problems is detected.

Moreover, hotels rate themselves with "stars" without meeting international requirements, which is an instance of deceiving customers. Despite the absence of regulations, hotels have access to the ratings provided by unbiased guides/evaluators or famous organizations, if they so desire. Guides/evaluators such as Lonely Planet and Brandt update information about our country every three years. Any hotel, hostel or family hotel can become featured in the guidebook. Representatives of the company assess service quality themselves and eventually publish it in the upcoming issue of the guidebook.

Adjara and Tbilisi dominate the hotel market in Georgia. According to the database of the National Tourism Administration of Georgia, the total number of accommodations were 1,475 by 2015 , and the number of beds equaled to 51,404 (Report, 2015, p. 24). It is noteworthy that family hotels make up an important segment of the hospitality industry. Along with low prices, a tourist has a wider choice and a closer contact with the locals. Also, this kind of hotels are a very good source of employment. However, there are international instructions for family hotels as well pertaining to what rooms for holidaymakers should be like (for example, a single room should be at least $9 \mathrm{~m}^{2}$, and a double room sized $12 \mathrm{~m}^{2}$ should have a window and an independent entrance, there should not be personal belongings of the host there, etc.), what kind of service they should be offered, etc. Sometimes, this information does not reach hotel owners. Thus, even basic rules are violated. Many are not aware of these standards and cannot meet them either, which largely affects service quality and visitor satisfaction.

It is important that a new component - support of hotel construction and expansion - will be added to the current government programme "Produce in Georgia". In line with the new component, an entrepreneur willing to build a new hotel or to expand one already available in the region, in case of getting a bank loan approval, shall benefit from the state co-financing scheme and contribution to mortgage assurance. Also, if an entrepreneur decides to bring an 
international operator in Georgia, the state is ready to co-operate in terms of the costs related to brand operation during the first two years.

Accounting problems related to tourism revenue are one of the most important problems not only in terms of legislative regulation but also in terms of studying financial and economic processes. For instance, accounting incomes generated from accommodations let to tourists by private persons is unregulated, which harms the national budget. The information about tourism statistics is insufficient. This problem can be eradicated by implementation of the Tourism Satellite Account developed by the World Tourism Organization.

It is noteworthy that the Tourism Development Strategy for Georgia 2015-2025 considers revision of legal norms for the development of the field of tourism in order to improve the business and investment environment and to integrate into the international tourism market effectively. In particular, it considers supporting the implementation of legal norms in terms of imposing privileges and developing other forms of economic cooperation between the state and private companies in relation to natural and cultural heritage monuments and state-owned parcels of land; it is planned to update the legislative package related to the tourism sector; to continue works in order to eradicate investment barriers and to ensure the enhancement of investors' trust in the field of tourism; to impose privileges on developing transportation sector and building new accommodation, convention centers, concert halls and other public buildings; to reduce visa requirements (Report, 2015, p. 22), etc.

Moreover, it is important to analyze and complete the national legislative base within the framework of the EU-Georgia Association Agreement for effective harmonization of laws. Articles 328-331 of the Association Agreement concern cooperation in the field of tourism. In particular, "the Parties shall cooperate in the field of tourism, with the aim of strengthening the development of a competitive and sustainable tourism industry as a generator of economic growth and empowerment, employment and international exchange" (DCFTA, 116).

\section{DONCLUSION}

Thus, studying the legal framework regulating the tourism business clarifies that a number of issues are left without legal regulation. In particular, regulations on standardization, certification and licensing of tourist objects that do not meet international standards; in order to enhance investors' trust in the 
field of tourism, it is necessary to reduce legal barriers and to ensure a better protection of property rights. Moreover, is important to analyze and complete the national legal framework within the framework of the EU-Georgia Association Agreement for effective harmonization of laws as well as to provide trainings and consultations on legal issues in order to increase legal awareness and use it in practice effectively.

\section{REFRENCES}

Economic Impact of Travel and Tourism 2015, Annual Update, WTTC.

Lekashvili, E. (2015), Entrepreneurial Way of Thinking and Its Development Challenges in Georgia. L'Association 1901 „SEPIKE”, Journal, Ausgabe 8,m Osthofen, Deutchland, Patiers, France, Los Angeles, USA, pp. 121-126.

Lekashvili, E. (2015), Tbilisi as an Agent of Tourism Market Tbilisi, First International Conference Economic, Legal and Social Problems of Modern Development - 2015; November 13-14, 2015; Akaki Tsereteli State University, http://atsu.edu.ge/EJournal/BLSS/eJournal/Papers/Tourism/LekashviliEka.pdf (Georgian edition) (accessed: 05.04.2016).

Manual for Inbound Tourism Business Planning. First edition (2015), The National Tourism Administration of Georgia.

OECD Tourism Trends and Policies 2014, http://www.oecd-ilibrary.org/Policies 2014 (accessed: 22.02.2015).

Resolution N279 of the Parliament of Georgia (June 23, 2015), on the procedure for according the status of a Tourist Enterprise to a person as well as the procedure for its operation and cancellation.

The Deep and Comprehensive Free Trade Area Agreement signed between the EU and Georgia (November 29, 2014).

The Law of Georgia Civil Code of Georgia (June 26, 1997).

The Law of Georgia on Supporting the Development of Free Tourist Zones (October 26, 2010).

The Law of Georgia on Tourism and Resorts (March 6, 1997).

The Law of Georgia Tax Code of Georgia (September 17, 2010).

The Ministry of Economy and Sustainable Development of Georgia, the National Tourism Administration of Georgia, Report 2015 (2016).

The Tourism Development Strategy for Georgia 2015-2025 (2015) first edition, the National Tourism Administration of Georgia (Georgian edition). 